\title{
IMPROVING THE MARKETING PERFORMANCE OF SMEs IN KUDUS REGENCY
}

\author{
Mira Meilia Marka \\ Universitas Muria Kudus, Kudus 59327, Indonesia
}

\begin{abstract}
This study used multiple regression analysis. The goal to be achieved is to analyze the influence of social capital and human capital on marketing performance. This study was aimed to develop and provide solutions to research gap problems in social capital and human capital towards marketing performance. The research sample is the 201 respondents involved with SMEs in Kudus. The results show that social capital has no significant effect on marketing performance and human capital has a positive and significant influence on marketing performance. The results show that the main problem faced by SMEs is human capital. SMEs can improve marketing performance through improving their business skills and product innovation.
\end{abstract}

Keywords: social capital, human capital, marketing performance

\section{INTRODUCTION}

In Indonesia, on average 99\% of businesses are SMEs. SMEs have a large proportion in growing business units in Indonesia such as micro businesses. SMEs are one of the pillars of the Indonesian economy that can improve the welfare of the community through the creation of jobs. The absorption of labor from SMEs that has been developed constitutes $97 \%$ of the national workforce.

During the covid-19 pandemic, SMEs experienced many obstacles in the development of their business that confer an impact on the national economy. Indonesia's economy in 2020 in the second quarter was minus 5.32\% (Purwanto, 2020). The Covid-19 pandemic impact survey on the performance of Indonesian SMEs conducted by LIPI in 2020 on 679 respondents stated that 94.69 percent of businesses experienced a decrease in sales (Jawapos.com, 2020). These

\footnotetext{
*Corresponding Author.

e-mail: mira.meilia@umk.ac.id
} 
conditions forces the company to improve its marketing performance. Marketing performance is a benchmark for achieving market share of a product (Sugiyarti, 2016).

The decline in market share occurred to SMEs in the Kudus area, specifically in Ngembalrejo village. Ngembalrejo village is located in Kudus Regency and it has an economic foundation driven by community efforts. Based on data obtained from the Ngembalrejo village government, the number of SMEs in Ngembalrejo Village in 2020 is around 405 SMEs with various products such as madu mongso, keciput, gapit, pastry, and tile.

Social capital as unity and concern among members of society is formed from rules, values, and beliefs (Pratisthita et al, 2014). Social capital plays an important role in building a harmonious society and strengthening relationships within every individual in society. Social capital is an important prerequisite for the success of a society. Social capital has a very high influence on the development and progress of various economic sectors (Heliawaty, 2016).

Social capital built from the close social network owned, trust between individuals or groups, adherence to norms and values contained in society, and the achievement of shared goals can affect the resources owned by businesses, competencies, and information and data needed. These factors support the improvement of SMEs performance (Saha and Banerjee,2015).

Good human capital is needed to achieve business performance targets because through their ability and skills may business productivity be significantly increased (Skuras 2005). Human capital consists of knowledge and skills possessed by the human resource through formal education, training, and work experience (Wajdi and Muzakar Isa, 2014). Based on the results of a research by Pasanen (2003), a business should be able to achieve appropriate efficiency through the background of human resources education that is able to support the work and create sufficient engagement in the field of marketing, production, or others to improve business performance.

Improving the quality of human resources is one of the factors that are the focus of attention by the current government. Based on Bates research (2005), the granting of capital to small industries in the initial development of their business has not delivered expected results. The condition is influenced by human resources owned by the SMEs. The HR has educational background but 
are lacking experience in advancing business. SMEs in Indonesia have also experienced the same thing and the government has provided support through the development capital but has not been able to provide significant changes (Thee, 2006).

The aspects of human capital development must be strengthened to improve the achievement of human capital and ultimately improve the company's performance. Wadji (2014) further explained that to make entrepreneurs more capable in improving the company's performance, the quality of human capital also needs to be improved in terms of skills, especially interpersonal skills and technical skills in the workplace.

Marketing performance is one of the indicators of success of the strategy implemented by the company. It reflects the company's performance as widely indicated by the development of profit obtained through increasing product sales volume, increasing number of consumers, increasing market share, and consumers becoming aware of the product (Elwisam and Lestari, 2019). Marketing performance is a key indicator of the success of marketing strategies carried out by SMEs. SMEs that have competent human capital and good social capital have one of the steps to improve business through marketing performance.

There are inconsistencies in the results of past studies, namely the results of Handoyo research (2015) which stated that social capital has no significant effect on marketing performance but the research of Layla $\mathrm{K}$ and Lindawati $\mathrm{K}$ (2014) stated that social capital supports the creation of marketing performance. The research results of Santoso, D, Indarto, Wyati (2019) and Prima Sandria and Widodo (2020) stated that human capital have a positive and significant effect on performance, but the research by Wulandari, W., Sodik, S., and Handini, D.P. (2020) stated that human capital has no significant effect on the performance of SMEs.

\section{LITERATURE REVIEW}

\subsection{Marketing Performance}

The SMEs is a factor that can be used to measure a policy that will be applied in conducting business. Policies are made to be directed in achieving good performance in handling financial performance, marketing, production, 
and human resources development. The performance of SMEs can also be related to marketing in achieving sales volume, market share, and market expansion (Chong, 2008).

Sampurno (2010) categorized marketing performance into several parts, namely the value of sales which is the size of the selling product in the market, sales growth by comparing the sales curve in a certain period, as well as the size of the portion owned by the product in the market. These three parts benefit the company in the form of revenue.

Marketing performance is the result achieved by the owner or manager in running the business. Marketing performance can be measured using sales growth, customer growth, and product success. Basically the purpose of the establishment of a company or business is to get maximum profit. Therefore, there is a need for continuity and improvement in marketing activities, while marketing is a social process consisting of individuals and groups who seek to obtain needs and desires by creating, offering, and exchanging valuable products with other parties (Sari, 2013).

Marketing performance is a benchmark of a company's success stemming from its product marketing activities (Merakti, Rusdarti and Wahyono, 2017). In marketing activities, the company prepares a variety of appropriate strategies in order to achieve the expected marketing performance. The company's strategy is planned in order to increase the company's revenue through the number of products sold in the market, the increasing market share owned, or the financial aspects of the company that are structured and in accordance with the target (Mawu, Mandey and Tawas, 2016). Marketing performance aims to increase profit for the company through activities stemming from interactions that occur with consumers. Manufacturers can provide understanding, build good communication, and convey value to the resulting product (Pertiwi and Siswoyo, 2016).

The size of marketing performance can be seen from Target Profit, Customer Growth, and Sales Turnoveor (Widjajanti, 2012). Ferdinand in Depary (2010) stated that the measurement of marketing performance is done with the number of units of sales, customer growth, customer turnover, more stated marketing performance, and competition. On the other hand, according to Sukarno in Depary (2010), the factors underlying marketing performance are satisfaction with profit, relative profit, repeat business, and customer retention. 


\subsection{Social capital}

The formed social capital can be shown from the establishment of good spirit and cooperation between individuals in the company so as to have a positive impact on the company and individuals in it. Social capital will increase its influence on other capitals in the company (Putnam, 2000). Social capital is the amount of resources, both actual or virtual, collected by an individual or group because it has a durable network, in the form of reciprocal relationship between introduction and recognition. There are two forms of social capital, namely exclusive or binding social capital and inclusive or bridging social capital (Field, 2010). Social capital is the social relationship between economic actors and their relationships with economic institutions. Social capital is multidimensional and occurs at the individual and organizational level in the company. Social capital has two dimensions that have different implications on achievable outcomes and the emergence of the influence of life processes and community development (Suriatna, D, 2013).

Perceptions of social capital have sprung up and one of the perceptions about social capital was expressed by Ferdinand (2005). The perception consists of social networks or links owned by businesses, internal and external networks owned, prevailing norms, social cohesion, reciprocal norms, and a cooperation built in the company so that it takes the form of resources that can build marketing performance.

Social capital in the form of social networks become supporters of the creation of individual social relations in society. The relationship is based on norms of shared behavior and united by culture so as to improve the ability of individuals socially (Sudirah et al,2020). Similarly, Supriono (2008) stated that social capital is a built interaction and the quality and quantity of social relations relates to norms in the broad scope. Social capital is a supporting media for the creation of harmonization in society. Social capital according to Robison and Schmidt (2002) is a form of sympathy given to others through mutual care, mutual belonging, and mutual trust between each other.

In simple terms, social capital can be stated as a result of interactions that arise spontaneously and is a collection of non-formal order that encourages cooperation between individuals in one community (Supono,B, 2011). Factors 
that support the creation of social capital according to Oliveira (2013) is the number of networks of businesses, variations of networks, and the strength of networks owned by SMEs.

Businesses should be able to identify opportunities for increased business progress through social networks. Social networks play an important role in the success of sales. Well-built social networks will have an impact on increasing consumer awareness of a product. It is expected that consumers become interested in consuming the products offered by the company (Terziovski, Mile, 2003).

Strong social capital is able to create marketing performance. Social networks owned by SMEs can be a supporting system for business growth. With the existing network, SMEs can expand their market and target consumers. Entrepreneurs with similar products should be partners who work together in improving business growth.

\subsection{Human Capital}

Basically the concept of human capital consists of several aspects, namely education or intellect, skills, and work experience. In general, human capital can be interpreted as the result of a teaching process consisting of individual insights and skills during the productive period of a formal education, as well as training and work experience (Wajdi et al., 2018). Human capital is a personal factor, namely the skills and basic knowledge that individuals have (Ritonga, 2019). The next principle is external activities that can improve the abilities possessed by individuals through education and training that followed. Human capital education is not only about what is accepted in school such as skills that must be mastered, but also aspects of responsibility, discipline, and honesty. Education must always be put forward in order to get a decent life, because extensive knowledge is a strong human capital in facing the future because basically human beings can never be separated from knowledge. Another principle is that human capital is related to the company's goal in producing goods or services.

The form of human capital is the skills and expertise that become the qualitative dimension of human resources. In addition, it will also affect the productive ability of the person. According to Farah and Sari (2014), skills and 
knowledge can be improved with good education and as long as health is also maintained.

There is a capitalistic competition among capital holders that creates the impartiality of human capital theory. So, the importance of human resources who have the insights and skills that support business improvement is an investment of human capital (Andriani, 2019).

Human capital includes knowledge of entrepreneurs and also skills and abilities in innovating products. The increasing knowledge about the market and potential consumers, skills in business management, and product innovation that has been done, increase marketing performance. Therefore, human capital has an important role in the improvement of business.

\section{Conceptual framework}

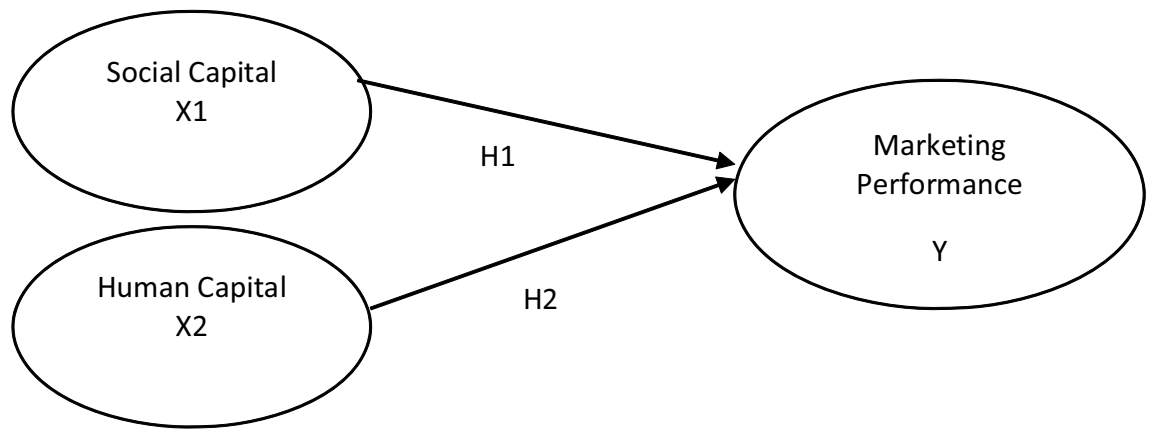

\section{RESEARCH METHODS}

This study uses quantitative method with multiple regression method, this method is used in a research that has more than one independent variable (Ghozali, 2018). Multiple linear regression analysis is used to determine the direction and how much influence the independent variable has on the dependent variable (Ghozali, 2011)

The research population is the SMEs in the area of Ngembalrejo, Kudus. The number of research population is 405 . SMEs in the district produces various types of products, namely SMEs snacks such as madu mongso, gapit, keciput, 
and tile. Samples in the study were obtained by using the slovin formula resulting in 201 respondents based on the following calculations.

$\mathrm{n}=\frac{N}{1+N e^{2}}$

Description:

$\mathrm{N}$ : research population size

n: research sample size

E: error

Calculation for the size of research samples with slovin formula:

$\mathrm{n}=\frac{405}{1+\left(405 \times 0,05^{2}\right)}$

$\mathrm{n}=\frac{405}{1+\left(405 x 0,0025^{2}\right)}$

$\mathrm{n}=\frac{405}{1+1,0125}$

$\mathrm{n}=\frac{405}{2,0125}$

$\mathrm{n}=201,24=201$ respondents

In this study, the researchers used simple random sampling. Simple Random Sampling is taking members of the sample from a population that is done randomly without paying attention to the strata in that population.

The data source used in the research is primary sources. A primary source is data obtained directly from the source. In this study, it is raw data from the dissemination of questionnaires to respondents, namely SMEs in the village of Ngembalrejo, Kudus Regency. Research data analysis technique used is quantitative analysis.

This analysis can be applied to data in the form of numbers and methods of discussion using statistical tests. The statistical analysis of this study is the analysis of multiple linear regressions. The stages of research analysis are validity test, reliability, multiple linear regression, goodness-of-fit test, and determination test. 


\section{DISCUSSION}

The validity test aims to identify the validity of the statement contained in the questionnaire. Questionnaire statements are considered valid or legitimate if they can provide an overview of the variables that the research model is modeling. In this test the level of trust used was 95\%. In the study, the results of the validity test showed that all questions in the questionnaire have a significance value of less than 0.05 and they are declared valid. On the reliability test the results showed a value of $>0.70$ and so the entire statement items used are reliable.

Table 1 F-Test Results

\begin{tabular}{|c|c|c|c|c|c|c|}
\hline \multicolumn{7}{|c|}{ ANOVA $^{a}$} \\
\hline \multicolumn{2}{|l|}{ Model } & $\begin{array}{l}\text { Sum of } \\
\text { Squares }\end{array}$ & df & Mean Square & $\mathrm{F}$ & Sig. \\
\hline \multirow[t]{3}{*}{1} & Regression & 72.485 & 2 & 36.242 & 51.314 & $.000^{\mathrm{b}}$ \\
\hline & Residual & 139.844 & 198 & .706 & & \\
\hline & Total & 212.328 & 200 & & & \\
\hline
\end{tabular}

a. Dependent Variable: Kinerja Pemasaran

b. Predictors: (Constant), Human capital, Sosial capital

Simultaneous social capital and human capital testing on marketing performance was conducted using the F-test and it obtained the result that the F-count value is 51,314 , which is more than the F-table 3041 with a significance rate of 0.000 that is less than 0.05 . Based on these results, the variables social capital and human capital have a positive and significant influence on marketing performance.

Advanced testing done is the multiple linear regression tests. The results of multiple linear regression analysis are shown in the following table.

Table 2 Multiple Linear Regression Analysis Results

Coefficients $^{\mathrm{a}}$

\begin{tabular}{|c|c|c|c|c|c|c|}
\hline \multirow[b]{2}{*}{ Model } & & \multicolumn{2}{|c|}{ Unstandardized Coefficients } & \multirow{2}{*}{$\begin{array}{c}\text { Standardized } \\
\text { Coefficients } \\
\text { Beta }\end{array}$} & \multirow[b]{2}{*}{$t$} & \multirow[b]{2}{*}{ Sig. } \\
\hline & & $\mathrm{B}$ & Std. Error & & & \\
\hline \multirow[t]{3}{*}{1} & (Constant) & 6.729 & .274 & & 24.540 & .000 \\
\hline & Sosial capital & .021 & .042 & .041 & .497 & .619 \\
\hline & Human capital & .301 & .044 & .555 & 6.801 & .000 \\
\hline
\end{tabular}

a. Dependent Variable: Kinerja Pemasaran 
The multiple linear regression equations used in the study were $\mathrm{Y}=6.729$ $+0.021 \mathrm{X} 1+0.301 \mathrm{X} 2$. The equation explains that the variable (X1), social capital, has a positive influence of 0.301 on marketing performance $(\mathrm{Y})$ and (X2), human capital variable, has a positive influence of 0.021 on marketing performance $(\mathrm{Y})$.

Table 3 Test Result of Coefficient of Determination

Model Summary

\begin{tabular}{ll|r|r|r} 
Model & $\mathrm{R}$ & R Square & \multicolumn{1}{c}{$\begin{array}{c}\text { Adjusted } \mathrm{R} \\
\text { Square }\end{array}$} & $\begin{array}{c}\text { Std. Error of } \\
\text { the Estimate }\end{array}$ \\
\hline 1 & $.584^{\text {a }}$ & .341 & .335 & .84041 \\
\hline
\end{tabular}

a. Predictors: (Constant), Human capital, Sosial capital

b. Dependent Variable: Kinerja Pemasaran

The determination coefficient test aims to measure the influence of independent variables in explaining the dependent variable. Based on the coefficient of determination test, the adjusted R-square value (R2) is 0.335 and this shows that independent variables are able to describe dependent variables by $33.5 \%$, while the remaining $66.5 \%$ is influenced by variables outside this research model.

Here are the explanations of the influence between variables in accordance with the research hypothesis:

1. Testing hypotheses between social capital and marketing performance.

Based on the results of the $t$ test, the calculated $t$ value is 0.497 with a significance level of 0.619 . Because $0.497<1.97$ and $0.619>0.05$, it is concluded that the social capital variable (X1) has a positive and insignificant effect on marketing performance. This result supports Hartono's research (2013) which stated that social capital has no effect on performance. In this case, social capital in the form of business networks does not affect the marketing performance of SMEs in Ngembalrejo. Entrepreneurs have networks and business partners, but have not been able to increase their businesses. Business partners with similar products provide less support among SME owners in business development. The existence of cooperation as well as sharing of information about products and production techniques are needed to increase business. However, it is not grown from the owners of SMEs. 
2. Testing hypotheses between human capital and marketing performance. The $t$ test result shows that the calculated $t$ value for the social capital variable is 6,801 with a significance rate of 0.000 . Because 6,801 $>1.97$ and $0.000<0.05$, the human capital variable (X1) have a positive and significant effect on marketing performance. These results are in line with the research of Andriani \& Zain (2010), Layla Khoirrini and Lindawati Kartika (2014). Human capital is in the form of skills, knowledge, and innovation capabilities owned by entrepreneurs. Entrepreneurs develop their management skills. Some entrepreneurs start doing bookkeeping in order to identify profits and expenses during a certain period. The legality of the product is also done to survive in the market. This is done by SMEs producing snack products such as madumongso. SMEs also innovate products so that the products are more attractive to consumers and have competitive advantages over competitor products. The innovation has been done is in the packaging of products such as snacks that has been packed in jars to have added value. Some of these factors can create marketing performance.

\section{CONCLUSION}

The results of research tests obtained shows the following points:

1. Social capital has a positive and insignificant effect on marketing performance. Social capital owned by SMEs has not been able to support marketing performance. Social networks owned by SMEs, namely consumers, partners, or suppliers have not been able to fully support the business developed.

2. Human capital has a positive and significant impact on marketing performance. Human capital owned by SMEs is able to support marketing performance. The higher the level of human capital, the more it can improve marketing performance. In other words, the improvement of knowledge, competence, and behavior of SMEs will have a positive impact on sales growth, customer growth, and sales volume.

Based on the results of the research, the following can be suggested:

1. The Entrepreneurs of SMEs in Ngembalrejo should establish good cooperation and communication with consumers and suppliers to get the information needed for business progress. 
2. In order to increase social capital, SMEs should utilize the internet in accessing information used to provide insights related to their products and businesses.

3. The local government has provided facilities to SMEs to develop knowledge and skills through various training activities. Entrepreneurs can dig up information about the facilities provided by the local government so that the SMEs can take advantage of these opportunities in order to improve their human capital.

\section{REFERENCES}

Adriani, E. (2019). Pengukuran modal manusia (suatu studi literatur). J-MAS (Jurnal Manajemen dan Sains), 4(1),176. doi: http://dx.doi.org/10.33087/ jmas.v4i1.86.

Andriani, N. \& Zain, D. (2010). Pengaruh modal sosial, kualitas informasi, dan Kompetensi pemasaran terhadap kinerja pemasaran (Studi pada industri kecil menengah garmen di Jawa Timur). Jurnal Aplikasi Manajemen,8(4), 1031-1038. https://jurnaljam.ub.ac.id/index.php/jam/article/view/309.

Bates, Timothy. (2005). Analysis of young, small firms that have closed: delineating successful from unsuccessful closures. USA Journal of Business Venturing, 20,343-358. doi: https://doi.org/10.1016/j.jbusvent.2004.01.003.

Chong, S. 2008. Success in electronic commerce implementation: a cross country study of small and medium sized enterprises. Journal of Enterprise Information Managemen, 21(5),468-92. doi: https://doi.org/10.1108/17410390810 904247.

Elwisam, E. \& Lestari, R. (2019). Penerapan strategi pemasaran, inovasi produk kreatif dan orientasi pasar untuk meningkatkan kinerja pemasaran UMKM. Jurnal Riset Manajemen dan Bisnis (JRMB), 4(2), 277-286. doi: https:// doi.org/10.36226/jrmb.v4i2.265.

Farah, A. \& Sari, E.P. (2014). Modal manusia dan produktivitas. JEJAK: Jurnal Ekonomi dan Kebijakan, 7(1), 22-28. doi 10.15294/jejak.v7i1.3840.

Ferdinand, A. (2005). Stuctural Equations Modeling dalam penelitian Manajemen. Semarang: Badan Penerbit Universitas Diponegoro. 
Mira Meilia Marka / Improving the Marketing Performance of SMEs in Kudus Regency

Ghozali, Imam. (2011). Aplikasi Analisis Multivariate dengan Program SPSS. Semarang: Badan Penerbit Universitas Diponegoro.

Ghozali, Imam. (2018). Aplikasi Analisis Multivariate dengan Program IBM SPSS 25. Semarang: Badan Penerbit Universitas Diponegoro.

Handoyo, Ag. Sunarno. (2015). The effect of marketing innovation, market orientation, and social capital on competitive advantage and marketing performance: A study in MSMEs of embroidery Central Java Province. Journal of Economics, Business, and Accountancy Ventura,18 (3),351-366. doi: 10.14414/jebav.v18i3.506.

Heliawaty, et al. (2016). Modal sosial: peran, unsur, dan pengaruhnya terhadap usaha tani padi "Pulu Mandoti" di Enrekang. Seminar Nasional Unmas Denpasar 29-30 Agustus 2016. https://jurnal.unmas.ac.id/index.php/pros/ article/view/381.

Layla Khoirrini \& Lindawati Kartika .(2013). Pengaruh modal insani dan modal sosial terhadap kinerja (studi kasus usaha kecil dan menengah (UMKM) makanan dan minuman kota Bogor). Jurnal Manajemen dan Organisasi, V(3). doi https://doi.org/10.29244/jmo.v5i3.12174.

Mawu, Mandey \& Tawas. (2016). Analisis pengaruh kompetensi pengetahuan pemasaran dan orientasi kewirausahaan terhadap kapabilitas pemasaran dan kinerja pemasaran (Studi pada wirausaha industri rumah kayu Kota Tomohon). Jurnal EMBA, 4(3), 173-183. doi https://doi.org/10.35794/ emba.v4i3.13672.

Merakti, I., Rusdarti, \& Wahyono (2017). Pengaruh orientasi pasar, inovasi, orientansi kewirausahaan melalui keunggulan bersaing terhadap kinerja pemasaran. Journal of Economic Education, 6(2),114-123. doi https:// doi.org/10.15294/jeec.v6i2.19297.

Oliveira, J.F.D. (2013). The influence of the social capital on business performance: an analysis in the context of horizontal business networks. RAM. Revista de Administração Mackenzie, 14(3), 209-235. https://www.scielo.br/pdf/ram/ v14n3/a09v14n3.pdf.

Pasanen, Mika. (2003). Multiple entrepreneurship among successful SMEs in peripheral locations. Journal of Small Business and Enterprise Development.10(4),418-425. doi http://dx.doi.org/10.1108/14626000310504729. 
Pertiwi, Yunita Dwi, \& Siswoyo, Bambang Banu. (2016).Pengaruh orientasi pasar terhadap kinerja pemasaran pada UMKM kripik buah di Kota Batu. Prosiding Seminar Nasional the 3rd Call for Syariah Paper Accounting FEB UMS, 231-238.

Prima Sandria \& Widodo. (2020). Innovative performance development model based on human capital and network quality toward improved marketing performance. Management Science Letters, 10, 659-664. doi http:// dx.doi.org/10.5267/j.msl.2019.9.013.

Putnam, Robert. 2000. Bowling Alone: The Collapse and Revival of American Community. New York: Simon and Schuster.

Ritonga, Z. (2019) . Analisis pengaruh human capital terhadap kinerja karyawan pada PT Mustika Asahan Jaya. Ecobisma (Jurnal Ekonomi, Bisnis dan Manajemen), 6(1), 23-28. doi https://doi.org/10.36987/ecobi.v6i1.16.

Robison \& Schmidt. (2002). Social capital and poverty reduction: toward a mature paradigm. Department of Agricultural Economics, Michigan State University, 614 http://dx.doi.org/10.22004/ag.econ.10941.

Saha, M. \& Banerjee, S. 2015.Impact of social capital on small firm performance in West Bengal. The Journal of Entrepreneurship, 24 (2), 91-114. doi https://doi.org/10.1177\%2F0971355715586893.

Santoso, D., Indarto, \& Wyati, S. (2019). Pola peningkatan kinerja bisnis UKM melalui modal sosial dan modal manusia dengan kebijakan pemerintah sebagai moderating. Dinamika Sosial Budaya, 21 (2), 152-171. doi http:/ /dx.doi.org/10.26623/jdsb.v21i2.1764.

Sampurno. (2010). Manajemen Strategik: Menciptakan Keunggulan Bersaing yang Berkelanjutan (Edisi Pertama. Cetakan Ketiga). Yogyakarta: BPFE.

Skuras, Dimitris, Meccherib, N., Moreirac, M.B., Roselld, J., \& Stathopouloua, S. (2005). Entrepreneurial human capital accumulation and the growth of rural businesses: A four-country survey in mountainous and lagging areas of the European Union. Journal of Rural Studies, 21, 67-79.

Soekarwo. (2020). Mewujudkan UMKM sebagai Fondasi Perekonomian. Desember 2020. https://www.jawapos.com/opini/02/11/2020/mewujudkan-umkmsebagai-fondasi-perekonomian/. 
Sudirah, S., et al. (2020). Hubungan penguatan modal sosial, mitigasi bencana banjir, dan peningkatan produksi pertanian. Equilibrium: Jurnal Pendidikan, 8(1), 75-84. doi http://dx.doi.org/10.26618/equilibrium.v8i1.3094.

Suriatna, Danny. (2013). Analisa modal sosial dan inovasi produk pada pengusaha mikro dan kecil di Jawa Timur. Jurnal Agora,1(3). http://publication.petra. ac.id/index.php/manajemen-bisnis/article/view/1126.

Sugiyarti, Gita. (2016). Analisis kinerja pemasaran usaha kecil menengah batik di Provinsi Jawa Tengah. Prosiding Seminar Nasional Multi Disiplin Ilmu \& Call for Papers Unisbank (Sendi_U) ke-2. https://www.unisbank.ac.id/ojs/ index.php/sendi_u/article/view/4252/1258.

Supono, B. (2011). Peranan modal sosial dalam implementasi manajemen dan bisnis. Jurnal Ekonomi dan Kewirausahaan, 11(1), 10-16. http://ejurnal. unisri.ac.id/index.php/Ekonomi/article/view/348.

Terziovski, M. (2003). The relationship between networking practices and business excellence: a study of small to medium enterprises (SMEs). Measuring Business Excellence, 7(2), 78-92. https://doi.org/10.1108/13683040310478011.

Thee, Kian W. (2006). Policies for private sector development in Indonesia; sme promotion policies for Indonesia. ADBI, Asian Development Bank 46. https://www.econstor.eu/bitstream/10419/53512/1/511716907.pdf.

Wadji, M. Farid \& Muzakar Isa. (2014). Membangun konsep modal manusia yang berperan dalam kinerja pemasaran industri kecil. Seminar Nasional dan Call Paper, Research Methods and Organizational Studies.

Wajdi, M.F., et al. (2018) .Peranan aspek-aspek modal manusia pengusaha. Jurnal Ekonomi Manajemen Sumber Daya, 20(2), 104-111 https://doi.org/ 10.23917/dayasaing.v20i2.7388.

Widjajanti, Kesi \& Aprih Santoso. (2012). Pemodelan Kemitraan yang Berorientasi Pasar dalam Mendukung Peningkatan Kinerja UKM Industri Mebel. Semarang: Fakultas Ekonomi/Manajemen, Universitas Semarang.

Wulandari, W., Sodik, S., \& Handini, D.P. (2020). Orientasi belajar dan komitmen terhadap kinerja UKM melalui human capital sebagai variabel intervening pada UKM kerajinan di Malang Raya. Equilibrium: Jurnal Ilmiah Ekonomi, Manajemen, dan Akuntansi, 9(2). http://dx.doi.org/10.35906/je001.v9i2.573. 
Review of Management and Entrepreneurship

Volume 05, Number 01, April 2021 